Journal of Social Sciences 5(3): 236-238, 2009

ISSN 1549-3652

(C) 2009 Science Publications

\title{
Differences between Learning Styles in Professional Courses at University Level
}

\author{
Zebun Nisa Khan \\ Department of Education, \\ Aligarh Muslim University, Aligarh -202002, India
}

\begin{abstract}
Problem statement: As shown by research studies, knowledge of learning styles of students on the part of teachers is helpful in enhancing effectiveness of teaching-learning process. The present study was conducted to study and compare learning styles of students pursuing different professional courses at the university stage. The ultimate purpose was to facilitate learning in professional education in Indian conditions by way of improving learning styles of learners. Approach: The sample consisted of 200 students studying in B. Tech., MBBS, LLB and MBA courses selected from Aligarh Muslim University Aligarh, India, by using cluster sampling method. For measuring learning styles, Honey and Mumford's Learning Style Questionnaire (LSQ) was used which was considered appropriate in terms of its validity and reliability. For analyzing data Student's tstatistic was applied which is useful for comparing mean scores based on two groups at a time. Results: The students pursuing various professional courses were compared on four dimensions of learning styles, namely, activist, reflector, theorist and pragmatist. The study led to some useful conclusions. It was found that B. Tech. and MBBS students differed significantly on reflector and theorist dimensions and those of M.B.A. and B. Tech. also differed on the same dimensions. The students of LLB and MBA differed on activist and theorist dimensions while students of MBBS proved better than those of MBA on activist reflector and theorist dimensions. The students of LLB and B. Tech. and those of LLB and MBBS, also differed significantly on the same dimensions. The students of LLB and MBA did not show significant differences on any aspect of learning style. Conclusion: The findings of the study provided, useful guidelines to teachers of all professional courses to improve their teaching styles. They should devise their teaching strategies in such a way that students of varying learning styles may take their full advantage.
\end{abstract}

Key words: Learning style, professional courses, cluster sampling

\section{INTRODUCTION}

In recent years, the value of understanding student's learning styles for improving learning as well as scholastic achievement has been paid much attention by the educators, psychologists and researchers. They have developed a number of models of learning styles. Payton et al. ${ }^{[4]}$ suggest that knowledge of personal learning styles will enable students to identify their weaknesses so that they could participate more effectively in activities that contribute to most to their learning as well as participate in learning tasks, which may prove more efficient.

$\mathrm{Kolb}^{[2]}$ found that undergraduate business students tended to have accommodative learning style. Engineering students tended to have convergent learning style, while English and Social Sciences students (History, Political Science, Psychology, Economic and Sociology) tended to have assimilative learning style.
Science (Physics) students tended to have either convergent or assimilative learning style. Verma and $\mathrm{Kumar}^{[8]}$ revealed remarkable difference in learning styles of Arts, Science and Commerce students. Methew ${ }^{[3]}$ reported that students preferred learning styles into instructional design can benefit the quality of the learning environment and consequently, result in student's positive learning outcomes. Vermilten et al. ${ }^{[10]}$ revealed that significant differences existed between students of Private Law, Criminal Law and Administrative Law with regard to their learning styles. Verma ${ }^{[9]}$ found that there is variability in learning styles of University students in different courses i.e., Law, Social Sciences, Mathematics, Teacher Education and Natural Science. It is expected that such differences may be observed in Indian conditions also.

Objectives: In specific terms, the study seeks to find out the differences between learning styles of students 
in different Professional courses at University level. The study is aimed at achieving the following objectives:

- To study the difference between learning styles of MBBS and B. Tech. students

- To study the difference between learning styles of MBA and LLB students

- To compare learning styles of students of professional courses viz B. Tech, MBBS, MBA and LLB

- To give suggestions regarding the improvement in learning styles of students in aforementioned Professional courses

\section{MATERIALS AND METHODS}

The sample comprised of 200 students of Last Semester of B. Tech, MBBS, LLB and MBA studying in Aligarh Muslim University, Aligarh, India, using the Cluster Sampling Technique. The above research revealed that a number of models of learning styles developed by eminent researchers Honey and Mumford Model $^{[1]}$ is considered to be promising in the present study. According to this model, there are four distinct learning styles as below:

- Activist: Activists learning style involve the students fully and without bias in new experience. They enjoy the 'here and now' and are happy to be dominated by immediate experiences. They are open-minded, not skeptical. They tend to thrive on the challenge of new experiences ${ }^{[7]}$

- Reflector: Reflectors like to stand back to ponder experiences and observe them from many different perspectives. They collect data, both first hand and from others and prefer to chew thoroughly before coming to any conclusions

- Theorist: Theorists adopt and integrates observations into complex but logically sound theories. They assimilate disparate facts into coherent theories. They like to analyze and synthesize. They are keen on basic assumptions, principles, theories, models and systems thinking

- Pragmatist: Pragmatists are keen on trying out ideas, theories and techniques to see if they work in practice. They are essentially practical, down to earth people who like making practical decisions and solve problems. They positively search out new ideas and take the first opportunity to experiment with applications
Honey and Mumfords Leaning Styles Questionnaire (LSQ) was employed to assess learning styles of students of (B. Tech., MBBS, LLB and MBA) of four different courses. It consists of 80 statements of true/false type covering above-mentioned four learning styles. Respondents were asked to either tick or cross. The maximum possible score was $20 \%$ in each scale. The LSQ has a reliability 0.89 and satisfactory validity for the separate sub scales.

Statistical technique: The obtained data were analyzed by using t-test for finding out significant differences in mean learning style scores of the two groups at a time. The facility of computer was employed. The significance was tested at 0.5 and 0.1 level of significance.

\section{RESULTS}

- The difference in learning styles of B. Tech. and MBBS were found to be significant (2.45 t-value) in reflector and 4.82 in theorists. Similar results reported by $\mathrm{Kolb}^{[2]}$

- Significant differences were found in learning styles of reflectors (5.21 t-value) and theorists (7.87 t-value) at 0.01 level of significance in the case of MBA and B. Tech. students. This is in consonance with the finding of Verma ${ }^{[9]}$

- Differences in learning styles of MBA and LLB were ascertained by $\mathrm{t}$-test. It was found that MBA and LLB students were significantly different in activist (2.35 t-value) and theorist (2.96 t -value) learning styles and in others they were insignificant. Shaw ${ }^{[6]}$ also found the similar results

- $\quad$ Except in the area of pragmatist, MBBS group has shown significantly better learning styles of activist $(\mathrm{t}-2.72)$, reflector (t-6.89) and theorist ( $\mathrm{t}-5.71)$ as compared to MBA group. This conclusion also finds support by Plovmick ${ }^{[5]}$

- Activist, reflector and theorist are the three learning styles whose significant differences were marked as 2.87, 2.89 and 6.91. t-value (between the students of LLB, B. Tech and the same position was also noticed between the students of LLB and MBBS)

- Learning styles of LLB and MBA students has not showed any remarkable differences in any of the four areas. The finding is supported by Verma ${ }^{[9]}$

\section{DISCUSSION}

Students who do not perform well in above mentioned Professional courses are not better than 
those who fail to perform because their chances of employment and efficient working are bleak. The efficiency of a person in above Professions depends not only on education and training received by him/her but also on some of his /her personal learning styles.

- The results of the study have implications for the teachers that they should tailor their teaching strategies based on learning styles of the students because matching of the two groups yields productive results in forms of learning and retention of the students. It has also been supported by $\mathrm{Kolb}^{[2]}$. Not only this, it may generate more interest in teaching-learning process. Teachers may go a step a head in designing evaluatory tests. The knowledge of learning styles of students may be utilized for structuring the questions accordingly. Similar conclusion has also derived by Methew ${ }^{[3]}$ The assessment area offers a new filed of further research. This is an important area for further research because if the actual assessment of ability is biased in favor of those who are able to use their analytical skills more effectively, then employment selection criteria based, for example, on the degree classification may favor the wrong type of candidate in some circumstances. Plovmick ${ }^{[5]}$ also obtained the similar result

- It has been repeatedly stated by educational psychologists and theorists that, other things being equal, learning depend heavily on student's learning styles. The learning styles develop over time and on the basis of long experience with learning. A person's life experiences form his learning styles which in turn affect his learning. The learning styles also depend on the nature of the learning material. Similar conclusion has also been derived by Vermilten et al. ${ }^{[10]}$

\section{CONCLUSION}

The study shows that students of different professional courses have different learning styles. This finding has significant implications for development of curriculum and methods of teaching in these courses. The findings also give definite direction to policy makers and curriculum planners. The teaching methods in these courses should be devised keeping in view the differences in learning styles .Unfortunately, in Indian conditions, teachers of these professional courses follow the same techniques for all students. In fact, they require special training. Pre service and in-service courses should be devised for teachers of these courses before they are posted in the institutions.

\section{REFERENCES}

1. Honey, P. and A. Mumford, 1982. The Manual of Learning Styles, Maidenhead, England. DOI: 10.1037/0033-2909.133.3.46...

2. Kolb and A. David, 1981. Learning Styles and Disciplinary Differences. In: The Modern American College, San Francies C.A. Jossey-Bass, Chickering, A.W. and Associates (Ed.). ISBN 0875894666, pp: 232-255.

3. Mathews, D., 1996. An investigation of learning styles and perceived academic achievement for high school students. Clearning House, 69: 249-254. http://eric.ed.gov/ERICWebPortal/custom/portlets/ recordDetails/detailmini.jsp?_nfpb=true\&_\&ERIC ExtSearch_SearchValue_0=EJ530454\&ERICExtS earch_SearchType_0=no\&accno=EJ530454

4. Payton, Q., A. Heuter and B. Mac Donald, 1979. Learning styles preferences. Physical Therapy, 59: 147-152.

http://etd.lib.ttu.edu/theses/available/etd-073120083129501

5. Plovmick, M., 1975. Primary care career choices and medical student learning styles. J. Medical Educat., $\quad 50$ : 849-855. http://eric.ed.gov/ERICWebPortal/custom/portlets/ recordDetails/detailmini.jsp?_nfpb=true\&_\&ERIC ExtSearch_SearchValue_0=EJ124434\&ERICExtS earch_SearchType_0=no\&accno=EJ124434

6. Shaw, P.C., 1999. Learning style preferences among students at Mid Western Public University in the United States. Dissertation Abstracts Int., 60: 2331-A.

7. Tamir, P., 1975. Relationship between cognitive preference, school environment, Teachers curricular bias, curriculum and subject matters. Am. Educ. Res. J., 12: 235-240.

http://www.questia.com/PM.qst?a=o\&se $=$ gglsc $\& d$ $=76954603-33 \mathrm{k}$

8. Verma, B.P. and K. Ramesh, 1996. Study involvement and learning styles of women students as related to residential background. Academic stream and Type of institution. Indian Educ. Rev., 31: 99-111.

9. Verma, P., 2006. Variability in learning styles of university students in different courses. Indian J. Psychometry Educ., 37: 156-160.

10. Vermilten, Y.J., H.G. Lodewijks and J.D. Vermunt, 1999. Consistency and variability of learning strategies in different university courses. Higher Educ., 37: 1-21.DOI: 10.1023/A:1003573727713 